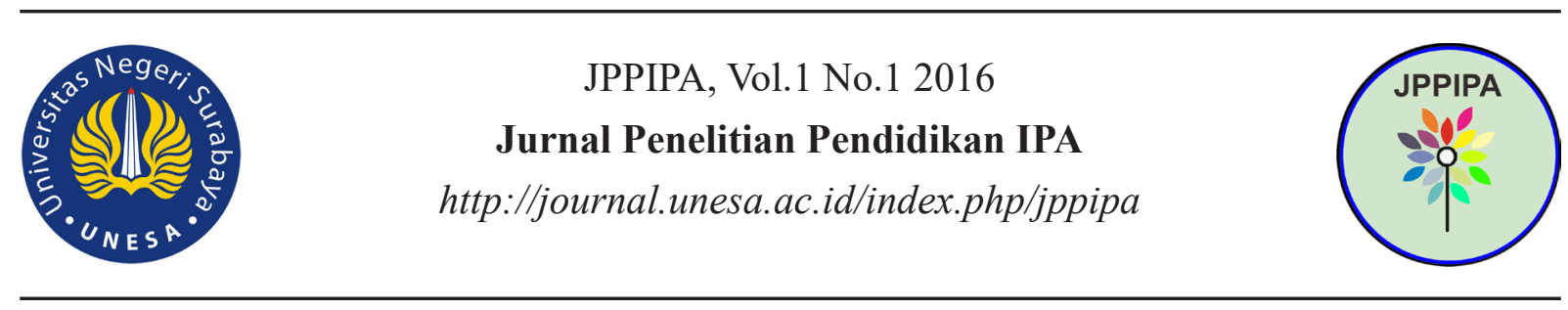

\title{
PENGEMBANGAN INSTRUMEN MOTIVASI BELAJAR FISIKA: ANGKET
}

Oleh:

Elok Sudibyo $^{1}$, Budi Jatmiko², Wahono Widodo ${ }^{3}$

1,3 Jurusan Ilmu Pengetahuan Alam, Fakultas Matematika dan Ilmu Pengetahuan Alam

Universitas Negeri Surabaya

${ }^{2}$ Jurusan Fisika, Fakultas Matematika dan Ilmu Pengetahuan Alam,

Universitas Negeri Surabaya

\begin{abstract}
Abstrak
Makalah ini memaparkan langkah-langkah dalam pengembangan instrumen motivasi belajar, khususnya terkait dengan penentuan aspek-aspek motivasi belajar fisika yang dapat digunakan sebagai dasar dalam merumuskan indikator-indikator motivasi belajar tersebut. Adapun aspek-aspek motivasi belajar yang digunakan sebagai dasar dalam pengembangan instrumen motivasi tersebut, meliputi: Choice of tasks, Effort, Persistence, dan Self-confidence. Berdasarkan keempat aspek motivasi tersebut, selanjutnya dirumuskan indikator-indikator motivasi belajar fisika. Akhirnya, indikator-indikator itulah yang dipakai sebagai dasar untuk merumuskan butir-butir pernyataan dalam suatu angket sebagai instrumen untuk mengukur motivasi belajar fisika. Instrumen motivasi belajar tersebut berupa angket dengan menggunakan skala Likert. Berdasarkan hasil pengujian, ternyata instrumen motivasi belajar fisika yang dikembangkan ini memiliki nilai keterbacaan Baik, validitas isi juga Baik, bahkan dapat dikatakan Sangat Baik, yaitu dengan nilai 4,52 dari nilai maksimal 5. Sedangkan derajat reliabilitasnya Sangat Tinggi, yaitu dengan ditunjukkan oleh nilai koefisien korelasi sebesar 0,948. Derajat reliabilitas instrumen tersebut diperoleh dengan metode test-retest dengan tenggang waktu antara pengambilan Data I dan Data II yaitu selama dua minggu.
\end{abstract}

Kata Kunci: choice of tasks, effort, persistence, self-confidence, motivasi belajar.

\begin{abstract}
This paper describes the steps in the development of instruments of learning motivation, particularly related to determining the motivational aspects of learning physics that can be used as a basis for formulating the indicators of the learning motivation. The motivational aspects of learning is used as a basis for the development of instruments of motivation involving Choice of tasks, Effort, Persistence, and self-confidence. Based on these four aspects of motivation, then formulated indicators of motivation to learn physics. Finally, the indicators are used as the basis for formulating the items of statement in a questionnaire as an instrument to measure the motivation to learn physics. The instrument is a questionnaire using Likert scale. Based on test results, the instrument had readability and content validity level was in Very Good level, with a value of 4.52 (5 as maximum value). While the degree of reliability was Very High, which is indicated by the value of the correlation coefficient of 0.948. The degree of reliability of the instrument was obtained by test-retest method with a time retention between pilot project I and II, ie for two weeks.
\end{abstract}

Keywords: choice of tasks, effort, persistence, self-confidence, learning motivation.

(C) 2016 Universitas Negeri Surabaya

1Alamat Korespondensi:
Jurusan IPA FMIPA Universitas Negeri Surabaya
Gedung C12 Kampus Ketintang
E-mail: eloksudibyo@unesa.ac.id

E-mail: eloksudibyo@unesa.ac.id 


\section{PENDAHULUAN}

Motivasi merupakan salah satu unsur paling penting yang harus diperhatikan oleh guru dalam pembelajaran agar pembelajaran tersebut dapat berjalan secara efektif (Arends, 2012; Brophy, 2004; Palmer, 2005). Siswa yang termotivasi untuk mempelajari sesuatu akan menggunakan proses kognitif yang lebih tinggi dalam mempelajari materi itu, sehingga siswa itu akan menyerap dan mengendapkan materi itu dengan lebih baik (Driscoll, 2000; Jetton \& Alexander, 2001; Pintrich, 2003; yang dikutip oleh Slavin, 2009). Banyak penelitian yang menunjukkan bahwa motivasi belajar siswa terhadap suatu pelajaran merupakan faktor yang mempengaruhi prestasi siswa pada hasil belajarnya (Anderson II, 2007; Christidou, 2011; Kang, 2010; Palmer, 2005; Schunk, Pintrich, \& Meece; 2010; Sudibyo, 2008). Oleh karena itu, tugas guru bukan hanya sekedar menyampaikan materi pelajaran, namun tugas penting bagi guru adalah mengarahkan, meningkatkan, dan mempertahankan motivasi siswa untuk belajar, dan terlibat dalam aktivitas yang menuju pada pembelajaran.

Motivasi biasanya didefinisikan sebagai proses yang menstimulasi perilaku kita atau menggerakkan kita untuk bertindak (Arends, 2012). Santrock (2008) mendefinisikan motivasi sebagai proses yang memberi semangat, arah, dan kegigihan perilaku. Artinya, perilaku yang termotivasi adalah perilaku yang penuh energi, terarah, dan bertahan lama. Sedangkan Maehr \& Meyer (Brophy, 2004) menyatakan bahwa motivasi merupakan suatu konsepsi yang digunakan untuk menjelaskan inisiatif, arah, intensitas, kegigihan, dan kualitas perilaku, secara khusus perilaku ke arah tujuan. Schunk, Pintrich, \& Meece (2010) melihat bahwa motivation berasal dari kata kerja bahasa Latin movere dan mengacu pada "apa yang membuat individu bergerak" ke arah kegiatan dan tugas tertentu. Lebih lanjut, Schunk, Pintrich, \& Meece (2010) mendefinisikan bahwa motivasi adalah suatu proses yang mempengaruhi kegiatan ke arah tujuan dan sifatnya terus-menerus. Adapun, para ahli psikologi mendefinisikan motivasi sebagai suatu proses internal (dari dalam diri seseorang) yang mengaktifkan, membimbing, dan mempertahankan perilaku seseorang dalam rentang waktu tertentu (Murphy \& Alexander, 2000; Pintrich, 2003; Schunk, 2000; Stipek, 2002; yang dikutip oleh Slavin, 2009). Sejalan dengan definisi para ahli tersebut, Woolfolk (2010) juga mendefinisikan motivasi sebagai keadaan internal yang membangkitkan, mengarahkan, dan mempertahankan perilaku.

Berdasarkan berbagai definisi tentang motivasi di atas, maka dapat disimpulkan bahwa motivasi adalah proses internal yang mendorong seseorang melakukan kegiatan atau tugas tertentu untuk mencapai tujuan dan terjadi dalam rentang waktu tertentu. Jadi, motivasi belajar merupakan proses internal yang mendorong pebelajar untuk melakukan kegiatan atau tugas-tugas akademik untuk mencapai tujuan belajar dan mampu bertahan dalam rentang waktu tertentu.
Dan yang dimaksud dalam rentang waktu tertentu di sini adalah sampai pebelajar tersebut mencapai tujuan belajarnya. Lebih lanjut, secara khusus jika yang dimaksud adalah motivasi belajar fisika maka kegiatan atau tugas-tugas akademik yang dipilih oleh pebelajar adalah kegiatan atau tugas-tugas yang terkait dengan pembelajaran fisika.

Meskipun motivasi merupakan salah satu unsur paling penting yang harus diperhatikan oleh guru dalam pembelajaran, namun guru sering mengalami kesulitan untuk menilai tingkat motivasi belajar siswanya. Oleh karena itu, perlu dikembangkan suatu instrumen yang dapat digunakan guru untuk menilai motivasi belajar siswanya. Dalam makalah ini, penulis memaparkan langkah-langkah yang telah dilakukan dalam mengembangkan instrumen motivasi belajar fisika. Adapun instrumen yang dikembangkan dan dipaparkan dalam makalah ini adalah berbentuk angket dengan menggunakan skala Likert.

\section{METODE}

Secara garis besar, langkah-langkah yang telah dilakukan dalam proses pengembangan instrumen motivasi belajar fisika ini, meliputi: (1) penentuan aspek-aspek motivasi belajar,(2) perumusan indikatorindikator motivasi belajar fisika, (3) penyusunan butir-butir pernyataan angket motivasi belajar fisika, (4) pengujian keterbacaan, (5) pengujian validitas isi, dan (6) pengujian reliabilitas instrumen. Langkahlangkah pengembangan instrumen tersebut dilakukan dalam rangka untuk menghasilkan suatu instrumen yang baku. Dengan demikian instrumen motivasi belajar fisika yang dihasilkan ini diharapkan dapat digunakan untuk mengumpulkan data, dan data yang terkumpul tidak lagi dipertanyakan kevalidannya.

\section{Aspek-Aspek Motivasi Belajar}

Karena motivasi merupakan proses internal, yaitu terjadi dalam diri seseorang, maka kita tidak dapat menilai motivasi seseorang secara langsung. Namun demikian, kita dapat menyimpulkan bahwa seseorang itu termotivasi atau tidak dari perilaku-perilaku orang tersebut (misalnya: pilihan terhadap suatu tugas, upaya atau usaha yang dilakukan, ketekunan atau kegigihan dalam melakukan kegiatan) atau ungkapanungkapan secara verbal (misalnya, "saya benar-benar ingin mengerjakan tugas ini”). Selain itu, siswa yang termotivasi pada suatu mata pelajaran, maka siswa tersebut akan memperoleh nilai atau hasil belajar yang memuaskan pada pelajaran tersebut. Dengan demikian, hasil belajar juga dapat digunakan sebagai indikator apakah siswa tersebut termotivasi atau tidak pada suatu pelajaran tertentu.

Ungkapan di atas senada dengan yang disampaikan oleh Schunk, Pintrich, \& Meece (2010) yang menyatakan bahwa penilaian terhadap motivasi dapat dilihat dari indikator-indikator perilaku dari aspek-aspek motivasi yang mereka sebut sebagai Indexes of Motivation. Adapun indexes of motivation tersebut, yaitu choice of tasks, effort, persistence, and achievement. Sedangkan, Maehr \& Meyer setidaknya meng- 
identifikasi ada lima aspek motivasi, yaitu terkait dengan inisiasi (initiation), arah (direction), intensitas (intensity), kegigihan (persistence), dan kualitas (quality) suatu perilaku (Brophy, 2004). Keempat aspek motivasi yang oleh Schunk, Pintrich, \& Meece (2010) disebut sebagai indeks motivasi itu, pada dasarnya tidak jauh berbeda dengan yang disampaikan oleh Maehr \& Meyer (Brophy, 2004) tersebut. Aspek motivasi terkait initiation dan direction menurut Maehr \& Meyer, oleh Schunk, Pintrich, \& Meece dikategorikan sebagai aspek choice of tasks. Sedangkan aspek intensity masuk dalam kategori effort, dan aspek quality dikategorikan sebagai aspek achievement.

Beberapa psikolog yang mempelajari motivasi (Graham \& Weiner, 1996; Pintrich, Marx, \& Boyle, 1993; yang dikutip dari Woolfolk, 2008) memfokuskan pada lima pertanyaan dasar untuk menilai seseorang itu termotivasi atau tidak. Kelima pertanyaan tersebut, yaitu: (1) Apa pilihan yang dibuat oleh seseorang tentang perilakunya? Mengapa sebagian siswa, misalnya, memfokuskan diri pada PR sementara yang lain lebih suka menonton televisi; (2) Berapa lama waktu yang diperlukan oleh seseorang untuk memulai melakukannya? Mengapa sebagian siswa segera mulai mengerjakan PR, sementara yang lain menunda-nundanya; (3) Seberapa tinggi intensitas atau tingkat keterlibatan seseorang dalam kegiatan yang dipilih? Begitu siswa membuka buku pelajarannya, apakah siswa tersebut langsung terfokus mengerjakan tugas atau masih tidak jelas mengerjakan apa; (4) Apa yang menyebabkan seseorang tersebut tetap bertahan atau menyerah? Akankah seorang siswa mengerjakan seluruh tugas-tugas fisika atau hanya mengerjakan beberapa tugas saja; dan (5) Apa yang dipikirkan dan dirasakan seseorang selama terlibat dalam suatu kegiatan? Apakah siswa menikmati saat mengerjakan tugas-tugas fisika, merasa dirinya kompeten, atau mengkhawatirkan tes yang akan datang.

Berdasarkan uraian di atas, penulis mengkategorikan empat (4) aspek motivasi yang selanjutnya akan dirumuskan indikator-indikator dari setiap aspek tersebut. Adapun keempat aspek motivasi tersebut, antara lain: (1) Pilihan atau ketertarikan terhadap tugas/ kegiatan, (2) usaha atau upaya yang dilakukan untuk sukses, (3) ketekunan atau kegigihan, waktu yang digunakan untuk sebuah tugas, dan (4) rasa percaya diri selama terlibat kegiatan.

Aspek motivasi yang pertama adalah choice of tasks. Ketika siswa dihadapkan dengan berbagai kegiatan atau tugas-tugas yang dapat dikerjakan, dan siswa memutuskan untuk menentukan sebuah pilihan pada tugas tertentu, maka pilihan siswa pada tugas itu mengindikasikan bahwa siswa tersebut dalam keadaan termotivasi dengan tugas itu. Siswa menunjukkan ketertarikan mereka pada tugas yang dipilih dengan cara mengerjakan tugas itu baik di dalam atau di luar sekolah, termasuk ketika mereka memiliki waktu senggang. Siswa dapat memilih di antara berbagai kegiatan.

Aspek motivasi yang kedua adalah effort. Belajar sering tidak mudah. Siswa yang termotivasi untuk belajar adalah siswa yang mempunyai kecenderungan melakukan upaya untuk berhasil. Upaya secara fisik diperlukan atas tugas-tugas motorik, sedangkan upaya secara kognitif diperlukan untuk pembelajaran akademik. Siswa yang termotivasi untuk belajar kemungkinan besar mengeluarkan upaya mental lebih besar selama pembelajaran dan menggunakan strategi-strategi kognitif mereka. Strategi-strategi kognitif tersebut, misalnya: pengulangan informasi, pengorganisasian, monitoring tingkat pemahaman, dan penghubungan dengan materi baru untuk pengetahuan awal. Siswa percaya bahwa penggunaan strategi-strategi kognitif akan meningkatkan pembelajaran mereka. Aspek motivasi yang ketiga adalah persistence. Aspek ini terkait dengan waktu yang digunakan siswa untuk sebuah tugas. Siswa yang termotivasi untuk belajar kemungkinan besar lebih tekun, terutama ketika mereka menghadapi rintangan. Ketekunan adalah penting karena banyak pembelajaran yang memerlukan waktu dan kesuksesan tidak mungkin terjadi dalam waktu yang singkat. Ketekunan sebagian besar berarti selama pembelajaran dan ketika siswa menghadapi rintangan. Siswa dengan ketekunan tinggi akan bekerja lebih lama pada suatu tugas yang menantang daripada siswa yang memiliki ketekunan rendah.

Akhirnya, aspek motivasi yang keempat adalah self-confidence. Aspek ini terkait dengan apa yang sedang dipikirkan dan dirasakan oleh siswa selama terlibat dalam suatu kegiatan pembelajaran. Siswa yang merasa dirinya berkompeten akan menikmati saat mengerjakan tugas-tugas yang diberikan oleh gurunya. Selain itu, siswa yang percaya bahwa dirinya memiliki suatu kompetensi, siswa tersebut tidak pernah merasa khawatir ketika harus menghadapi tes-tes yang akan datang.

\section{Indikator-Indikator Motivasi Belajar Fisika}

Indikator-indikator motivasi belajar ini merupakan penjabaran yang lebih spesifik dari suatu aspek motivasi yang telah diuraikan sebelumnya. Dalam merumuskan indikator- indikator tersebut, selain berpedoman pada aspek- aspek motivasi yang telah diuraikan sebelumnya, penulis juga melakukan studi pendahuluan, yaitu menjaring respon mahasiswa terkait perilaku yang mereka tunjukkan ketika mereka "termotivasi" untuk mengikuti suatu mata pelajaran tertentu. Studi pendahuluan ini dilakukan pada mahasiswa baru angkatan 2011 S1 Pendidikan Sains-FMIPA Unesa yang berjumlah 85 mahasiswa. Perilakuperilaku mahasiswa tersebut dipakai sebagai acuan dalam mengembangkan indikator-indikator dari suatu aspek motivasi yang telah ditentukan oleh penulis.

Untuk memastikan bahwa responden telah memberikan responnya (jawaban) atas pertanyaan-pertanyaan yang telah diberikan tersebut betul-betul sesuai dengan realitasnya (apa adanya) atau tidak, maka penulis memberikan pertanyaan-pernyataan dan harus dijawab (direspon) oleh responden sebanyak dua kali dalam waktu yang berbeda. Dalam hal ini, Respon I dan Respon II berselang selama 2 minggu. Perilaku- 
-perilaku (indikator motivasi) yang memiliki konsistensi, yaitu yang ditulis sama oleh responden pada Respon I dan Respon II, selanjutnya diorganisasikan oleh penulis untuk dijadikan bahan acuan dalam merumuskan indikator-indikator motivasi.

Beberapa perilaku (indikator) yang teridentifikasi dan mencerminkan seseorang siswa termotivasi pada suatu mata pelajaran tertentu, berdasarkan hasil analisis konsistensi respon yang ditulis oleh responden, antara lain:

1. Selalu berusaha duduk di depan.

2. Selalu belajar dan mengerjakan soal-soal yang belum diajarkan (untuk pertemuan berikutnya).

3. Antusias mendengarkan dan memperhatikan pelajaran.

4. Aktif, jika ada yang tidak paham langsung bertanya.

5. Mau mencoba dan mencoba meskipun berulangkali gagal.

6. Suka mengerjakan tugas yang diberikan guru walaupun setiap pertemuan tugasnya banyak

7. Apabila disuruh maju ke depan untuk mengerjakan, selalu siap.

8. Ketika ditanya, selalu berusaha menjawab.

9. Selalu berusaha untuk bisa memahami informasi yang diperoleh.

10. Ada kemauan belajar tanpa disuruh-suruh.

11. Suka berdiskusi dengan guru.

12. Perasaan senang, saat jam pelajaran tiba.

13. Dengan senang hati melakukan tugas-tugas terkait pelajaran.

14. Lebih awal untuk mengerjakan tugas atau PR yang telah diberikan.
15. Memperoleh nilai yang baik, dan puas atas nilai yang diperoleh.

16. Sering membaca buku pelajaran tersebut.

17. Berusaha untuk mengerti (belajar ekstra).

18. Aktif pada saat pembelajaran, mempelajarinya di rumah, raut wajah tidak masam, tidak mengantuk sewaktu pelajaran berlangsung.

19. Tidak ingin pelajaran itu cepat diakhiri dan selalu menanti tugas-tugas yang menarik.

20. Tepat waktu dalam mengumpulkan tugas yang diberikan guru.

Beberapa indikator tersebut di atas merupakan hasil analisis terhadap respon mahasiswa dan yang telah memberikan responnya secara konsisten. Indikator-indikator tersebut selanjutnya oleh penulis dipakai sebagai "bahan acuan" untuk merumuskan indikator-indikator motivasi belajar fisika, dan selanjutnya berdasarkan indikator-indikator yang nantinya telah dirumuskan, akan dipakai sebagai dasar untuk menyusun butir-butir pernyataan dalam sebuah Angket (Instrumen Motivasi Belajar Fisika). Namun demikian, beberapa indikator yang belum tercakup dalam hasil studi pendahuluan ini, selanjutnya dirumuskan sendiri oleh penulis dengan mengacu aspek-aspek motivasi yang telah dikaji berdasarkan berbagai studi literatur yang telah ditelaah secara sisematis.

Berdasarkan hasil kajian pustaka dan studi pendahuluan yang telah dilakukan oleh penulis, selanjutnya penulis merumuskan aspek-aspek motivasi dan indikator-indikator motivasi belajar fisika sebegaimana yang telah ditunjukkan pada tabel 1 di bawah ini.

Tabel 1. Aspek dan Indikator Motivasi Belajar Fisika

\begin{tabular}{lll}
\hline Aspek motivasi & Indikator motivasi \\
\hline Pilihan atau ketertarikan & 1. & Tertarik untuk mengikuti kegiatan pembelajaran fisika. \\
terhadap tugas/kegiatan & 2. & Memutuskan untuk memilih mengerjakan tugas-tugas yang terkait \\
& dengan pembelajaran fisika daripada tugas-tugas lainnya. & Kesegeraan dalam mengerjakan tugas-tugas fisika. \\
& 4. & Usaha atau upaya yang dilakukan untuk sukses Menggunakan waktu \\
& & senggang dengan melakukan kegiatan \\
\hline Usaha atau upaya yang & 1. & Mempunyai kecenderungan melakukan upaya untuk berhasil. \\
dilakukan untuk sukses & 2. & Melakukan upaya mental lebih besar selama pembelajaran fisika. \\
& 3. & Menggunakan strategi-strategi kognitif dalam belajar fisika \\
\hline Ketekunan atau kegigihan, & 1. & Tidak mudah putus asa dalam belajar fisika ketika menghadapi suatu \\
waktu yang digunakan untuk & & rintangan (permasalahan). \\
sebuah tugas & 2. & Bekerja lebih lama pada tugas atau kegiatan fisika yang menantang \\
\hline Rasa percaya diri selama & 1. & Percaya bahwa dirinya memiliki kemampuan tentang fisika. \\
terlibat kegiatan & 2. & Menikmati saat mengerjakan tugas-tugas fisika. \\
& 3. & Tidak merasa khawatir untuk menghadapi tes fisika yang akan datang. \\
\hline
\end{tabular}

\section{Butir-Butir Pernyataan Angket Motivasi Belajar} Fisika

Motivasi dapat dinilai dengan berbagai cara, antara lain: pengamatan langsung, penilaian oleh orang lain, dan laporan-laporan diri, seperti yang ditunjukkan Tabel 2 (Schunk, Pintrich, \& Meece; 2010). Tabel tersebut mendaftar delapan butir kategori untuk menilai motivasi. 
Tabel 2. Metode untuk Penilaian Motivasi (Schunk, Pintrich, \& Meece; 2010, h. 13).

\begin{tabular}{ll}
\hline Kategori & Definisi \\
\hline Pengamatan langsung & $\begin{array}{l}\text { Pengamatan tingkah laku meliputi pemilihan tugas, usaha, dan } \\
\text { kegigihan. }\end{array}$ \\
\hline Penilaian orang lain & $\begin{array}{l}\text { Penilaian oleh observer terhadap karakteristik mahasiswa yang } \\
\text { mengindikasikan motivasi. }\end{array}$ \\
\hline Self-reports & Penilaian diri \\
\hline Angket & Daftar pertanyaan atau skala rating yang dijawab secara tertulis. \\
\hline Wawancara & Aktivitas menjawab pertanyaan secara lisan \\
\hline Stimulated recalls & $\begin{array}{l}\text { Pemanggilan kembali sesuatu yang diingat di masa lampau dengan } \\
\text { diberikan rangsangan. }\end{array}$ \\
\hline Think-alouds & $\begin{array}{l}\text { Pengucapan secara lantang hasil pemikiran, aksi, dan emosi selama } \\
\text { menampilkan kinerja. }\end{array}$ \\
\hline Dialog & Percakapan antar dua orang atau lebih. \\
\hline
\end{tabular}

Dari berbagai metode yang dapat digunakan untuk menilai motivasi belajar tersebut, dalam mengembangan instrumen motivasi belajar fisika, penulis menggunakan metode kuesioner (angket). Oleh karena itu, penulis harus merumuskan butir-butir pernyataan dari angket tersebut.

Adapun beberapa pertimbangan dipilihnya kuesioner sebagai metode dalam pengumpulan data, antara lain: (1) dapat mengumpulkan data dari sejumlah besar subjek secara bersamaan dibandingkan metode pengamatan dan wawancara; (2) data yang dikumpulkan lebih objektif dibandingkan menggunakan wawancara karena responden dapat memberikan responnya dengan lebih leluasa, tanpa dipengaruhi oleh sikap mental hubungan antara peneliti dan sub- jek penelitian, atau oleh waktu yang tersedia dalam memikirkan jawaban; (3) dapat menjaring informasi terkait proses-proses kognitif dan afektif, yang tidak mungkin diperoleh melalui pengamatan; dan (4) data yang terkumpul lebih mudah untuk dianalisis, karena pernyataan- pernyataan yang ditulis dalam angket bersifat tetap dan sama antara yang diajukan kepada satu responden dan yang diajukan kepada responden lain.

Pada Tabel 1 telah dirumuskan aspek dan indikator indikator motivasi belajar fisika. Berdasarkan aspek dan indikator-indikator tersebut selanjutnya dirumuskan butir-butir pernyataan dari kuesioner (angket). Rumusan butir-butir pernyataan kuesioner tersebut ditunjukkan pada Tabel 3.

Tabel 3. Rumusan Butir-butir Pernyataan Kuesioner Motivasi Belajar Fisika

\begin{tabular}{lll}
\hline \multicolumn{1}{c}{ Indikator } & & \multicolumn{1}{c}{ Butir Pernyataan } \\
\hline Tertarik untuk & - & Ada perasaan senang dalam diri saya ketika jam perkuliahan fisika tiba. \\
mengikuti kegiatan & - & Setiap perkuliahan fisika berlangsung, saya selalu berusaha untuk mencari \\
pembelajaran fisika & tempat duduk di depan. \\
& - & Saya selalu memperhatikan penjelasan dosen selama perkuliahan fisika \\
& berlangsung. \\
& Apabila saya belum mengerti dengan penjelasan dosen, saya segera \\
& menanyakannya. \\
& Saya tidak pernah lupa membawa buku-buku fisika termasuk petunjuk \\
& praktikum yang diperlukan dalam perkuliahan fisika. \\
& Saya selalu mengikuti perkuliahan fisika dengan antusias dan tidak pernah \\
& mengantuk.
\end{tabular}

Memutuskan untuk Saya akan mengerjakan tugas-tugas fisika sebelum melakukan kegiatan lain. memilih mengerjakan tugas-tugas yang terkait dengan pembelajaran fisika daripada tugastugas lainnya

\begin{tabular}{lll}
\hline $\begin{array}{l}\text { Kesegeraan dalam } \\
\text { mengerjakan tugas-tugas }\end{array}$ & $\bullet$ & $\begin{array}{l}\text { Ketika diberi tugas-tugas fisika, saya segera mulai mengerjakan tugas-tugas } \\
\text { tersebut. }\end{array}$ \\
fisika & $-\quad \begin{array}{l}\text { Saya selalu tepat waktu dalam mengumpulkan tugas-tugas yang diberikan } \\
\text { oleh dosen fisika. }\end{array}$
\end{tabular}




\begin{tabular}{ll}
\hline Indikator & Butir Pernyataan \\
\hline $\begin{array}{l}\text { Menggunakan waktu } \\
\text { senggang dengan } \\
\text { melakukan kegiatan yang } \\
\text { berhubungan dengan }\end{array}$ & $\begin{array}{l}\text { Saya sering menggunakan waktu senggang dengan melakukan kegiatan yang } \\
\text { berhubungan dengan fisika. }\end{array}$ \\
fisika & \\
\hline $\begin{array}{l}\text { Mempunyai } \\
\text { kecenderungan } \\
\text { melakukan upaya untuk } \\
\text { berhasil }\end{array}$ & $\begin{array}{l}\text { Saya selalu mengerjakan keseluruhan tugas-tugas fisika yang diberikan oleh } \\
\text { dosen, tanpa ada yang tidak dikerjakan. } \\
\text { Saat mengerjakan tugas-tugas fisika, saya selalu mengecek setiap langkahnya } \\
\text { karena ingin mengerjakannya dengan sempurna. }\end{array}$ \\
\hline
\end{tabular}

Melakukan upaya mental Jawaban atas pertanyaan yang diberikan dosen telah benar-benar saya pikirkan. lebih besar selama pembelajaran fisika

\begin{tabular}{lll}
\hline $\begin{array}{l}\text { Menggunakan } \\
\text { strategi-strategi kognitif } \\
\text { dalam belajar fisika }\end{array}$ & $\begin{array}{l}\text { Saya selalu melakukan pengulangan informasi yang telah diperoleh dalam } \\
\text { perkuliahan. }\end{array}$ \\
& $\begin{array}{l}\text { Untuk memahami keterkaitan antar konsep fisika, saya suka membuat peta } \\
\text { konsep. } \\
\text { - }\end{array}$ \\
& $\begin{array}{l}\text { Saya sering mempelajari terlebih dahulu materi yang akan dipelajari di } \\
\text { kampus sebagai pengetahuan awal. }\end{array}$
\end{tabular}

\begin{tabular}{lll}
\hline $\begin{array}{l}\text { Tidak mudah putus asa } \\
\text { dalam belajar fisika } \\
\text { ketika menghadapi suatu } \\
\text { rintangan (permasalahan) }\end{array}$ & • & $\begin{array}{l}\text { Saya tidak pernah putus asa saat mengerjakan soal-soal fisika meskipun } \\
\text { penyelesaiannya memerlukan pemikiran ekstra keras. }\end{array}$ \\
\hline $\begin{array}{l}\text { Bekerja lebih lama pada } \\
\text { tugas atau kegiatan fisika }\end{array}$ & $\bullet$ & $\begin{array}{l}\text { Saya sering mengerjakan tugas-tugas fisika sampai berjam-jam lamanya. } \\
\text { yang menantang }\end{array}$ \\
& $\begin{array}{l}\text { Saya sering berjam-jam membaca buku-buku tentang fisika. } \\
\text { Ketika melakukan kegiatan eksperimen fisika, saya sering berjam-jam } \\
\text { melakukan kegiatan tersebut. }\end{array}$
\end{tabular}

\begin{tabular}{lll}
\hline $\begin{array}{l}\text { Percaya bahwa dirinya } \\
\text { memiliki kemampuan } \\
\text { tentang fisika }\end{array}$ & $\bullet$ & $\begin{array}{l}\text { Ketika dosen bertanya tentang materi fisika, saya bersedia menjawab } \\
\text { pertanyaan dosen secara sukarela. } \\
\text { Saya tidak pernah gugup ketika harus menjawab pertanyaan dosen di kelas. }\end{array}$ \\
\hline $\begin{array}{l}\text { Tidak merasa khawatir } \\
\text { untuk menghadapi tes } \\
\text { fisika yang akan datang }\end{array}$ & $\bullet$ & $\begin{array}{l}\text { Saya tidak pernah merasa ketakutan dalam menghadapi tes-tes fisika. } \\
\text { Saya tidak perlu belajar terlalu keras ketika sudah mendekati ujian fisika. }\end{array}$ \\
\hline $\begin{array}{l}\text { Menikmati saat } \\
\text { mengerjakan tugas-tugas } \\
\text { fisika }\end{array}$ & Saya mengerjakan tugas-tugas fisika dengan senang hati. \\
\hline
\end{tabular}

Rumusan butir-butir pernyataan yang telah disusun berdasarkan indikator-indikator motivasi belajar fisika tersebut, selanjutnya digunakan untuk menyusun instrumen untuk menilai motivasi belajar fisika mahasiswa S1 Ilmu Keolahragaan terhadap perkuliahan fisika.

\section{Pengujian Keterbacaan dan Validitas Isi}

Instrumen motivasi belajar fisika yang telah tersusun selanjutnya diuji keterbacaan dan validitas isinya. Uji keterbacaan dan validitas isi ini dilakukan dalam dua tahap. Tahap pertama, pengujian keterbacaan dan validitas isi instrumen dilaksanakan melalui kegiatan presentasi dan diskusi mata kuliah Pengembangan Instrumen di program studi S3 Pendidikan Sains, Program Pascasarjana UNESA. Pada kegiatan tersebut, penulis mempresentasikan dan membagikan instrumen kepada audience yang terdiri dari 10 mahasiswa S3 Pendidikan Sains Angkatan 2011 dan 2 orang dosen pembina mata kuliah Pengembangan Instrumen. Melalui kegiatan diskusi, setelah sesi presentasi, baik mahasiswa S3 Pendidikan Sains maupun dosen pembina mata kuliah Pengembangan Instrumen memberikan masukan-masukan serta memberikan penilaian terhadap keterbacaan dan validitas isi instrumen tersebut. Berdasarkan penilaian yang dilakukan oleh 10 mahasiswa S3 Pendidikan Sains dan 2 dosen pembina tersebut, keterbacaan instrumen tersebut mendapat nilai Baik. Demikian juga dengan validitas isi instrumen tersebut juga dikategorikan Baik. Masukan-masukan pada tahap pertama ini digunakan untuk merevisi instrumen dan selanjutnya dilakukan pengujian tahap kedua. 
Pada tahap kedua, pengujian keterbacaan dan validitas isi tidak dilakukan oleh orang yang sama seperti pada tahap pertama. Uji keterbacaan pada tahap kedua ini dilakukan pada mahasiswa S1 Pendidikan Sains Angkatan 2011 yang berjumlah 85 orang mahasiswa. Hasil penilaian yang dilakukan oleh 85 orang mahasiswa terhadap keterbacaan instrumen tersebut dapat dikategorikan Baik, bahkan hampir mendekati Amat Baik.

Sedangkan, untuk pengujian validitas isi pada tahap kedua ini, penulis hanya melibatkan tiga orang pakar dibidang Pendidikan Sains. Pengujian validitas isi dilakukan untuk memastikan bahwa butir-butir pernyataan yang telah dirumuskan oleh penulis memang telah sesuai dengan indikator dan aspek motivasi yang digunakan sebagai acuan. Berdasarkan hasil validasi yang dilakukan oleh ketiga orang validator tersebut ternyata instrumen motivasi belajar fisika yang telah dikembangkan ini mempunyai nilai validitas isi yang dikategorikan Baik, bahkan dapat dikatakan Sangat Baik, yaitu dengan nilai rata-rata 4,52 dari nilai maksimal 5 .

\section{Pengujian Reliabilitas Instrumen}

Pengujian reliabilitas instrumen ini bertujuan untuk menguji kestabilan skor dan dilakukan dengan cara pengulangan pelaksanaan pemberian angket kepada responden. Pengujian ini didasarkan atas suatu konsep yang memandang bahwa apabila angket tersebut reliabel, maka pengulangan pemberian angket yang sama kepada responden yang sama, tidak akan mempengaruhi skor yang diperoleh responden tersebut (Ali, 2010; Gronlund, 2003). Pelaksanaan pengulangan tersebut dilakukan dalam jangka waktu yang secara rasional tidak memungkinkan responden mengingat kembali pernyataan-pernyataan yang diajukan dan menghafal jawaban atas skala sikap pada pemberian angket pertama. Namun, secara rasional ingatan responden terhadap substansi pernyataan-pernyataan dalam angket tersebut belum berkurang atau belum hilang. Ini berarti bahwa dalam pelaksanaan pengulangan tersebut harus memperhatikan rentang waktu pengulangan pelaksanaan pemberian angket. Di samping harus memperhatikan rentang waktu pengulangan, pelaksanaan pengulangan juga harus memperhatikan ada atau tidaknya tambahan pengalaman subjek terkait butir-butir pernyataan dalam angket. Ini berarti bahwa dalam pelaksanaan pengulangan harus diusahakan agar subjek dipastikan tidak mengalami tambahan pengalaman terkait butir-butir pernyataan dalam angket.

Dengan memperhatikan kriteria-kriteria pelaksanaan pengujian reliabilitas instrumen tersebut, maka penulis memutuskan untuk melaksanakan pengambilan data, baik Data I maupun Data II (pengulangan), dilaksanakan setelah serangkaian perkuliahan fisika telah berakhir. Dengan demikian, antara pengambilan Data I dan Data II tidak ada kegiatan perkuliahan fisika yang dapat mempengaruhi sikap mahasiswa dalam merespon pernyataan-pernyataan dalam angket tersebut. Sedangkan selang waktu antara pengambilan
Data I dan Data II berselang selama 2 minggu.

\section{Pengambilan Data I}

Pengambilan Data I dilakukan oleh penulis sendiri. Dalam hal ini, penulis sekaligus sebagai dosen pengampu mata kuliah fisika di program studi S1 Ilmu Keolahragaan UNESA. Waktu pengambilan Data I tersebut dilaksanakan pada tanggal 4 Juni 2012, setelah mahasiswa melaksanakan Ujian Akhir Semester mata kuliah fisika. Penulis memilih untuk membagikan angket bersamaan dengan jadwal Ujian Akhir Semester tersebut karena penulis ingin memastikan bahwa responden tidak mengalami tambahan pengalaman terkait butir-butir pernyataan dalam angket.

Responden dalam ujicoba ini adalah mahasiswa S1 Ilmu Keolahragaan Unesa Angkatan 2011 yang terdiri dari empat kelas paralel, yaitu Kelas A, B, $\mathrm{C}$, dan D, serta masing- masing kelas berjumlah 35 mahasiswa, sehingga jumlah responden keseluruhan adalah 140 mahasiswa.

Secara garis besar, pelaksanaan pengambilan Data I ini menggunakan prosedur sebagai berikut.

1. Penulis meminta agar semua mahasiswa tetap berada di dalam ruang ujian, meskipun telah menyelesaikan perkerjaan soalnya.

2. Dengan dibantu oleh teman pengawas, yang bertindak sebagai pengawas saat ujian berlangsung, penulis membagikan Angket: Motivasi Belajar Fisika.

3. Sebelum mahasiswa memberikan responnya atas butir-butir pernyataan yang tertulis dalam angket tersebut, responden diminta membaca petunjuk pada angket tersebut.

4. Penulis memberikan petunjuk tambahan yang belum tertulis dalam angket, yaitu meminta mahasiswa untuk menuliskan nomor induk mahasiswa (NIM) mereka pada bagian belakang angket yang telah mereka beri respon.

5. Mahasiswa diberi waktu maksimal 15 menit untuk memberikan responnya atas butir-butir pernyataan dalam angket tersebut.

6. Mahasiswa yang telah selesai memberikan responnya dipersilahkan untuk mengumpulkan angket dan diperbolehkan meninggalkan ruangan dengan tertib.

Selanjutnya, data yang telah diperoleh pada hari Senin, tanggal 4 Juni 2012 tersebut ditabulasi dan diskor. Data ini selanjutnya diberi kode sebagai variabel X, dan nantinya data yang diperoleh saat pengulangan (Data II) dikode sebagai variabel Y. Hal ini diperlukan karena nanti akan dihitung nilai korelasi antara variabel $\mathrm{X}$ dan variabel $\mathrm{Y}$ tersebut.

\section{Pengambilan Data II}

Pengambilan Data II dilaksanakan pada tanggal 18 Juni 2012 (berselang 2 minggu setelah pengambilan Data I). Dalam pelaksanaan pengulangan ini penulis memperhatikan kriteria terkait rentang waktu pengulangan. Pengambilan rentang waktu pengulangan selama 2 minggu tersebut karena menurut 
penulis bahwa jangka waktu tersebut secara rasional tidak memungkinkan subjek mengingat kembali pernyataan-pernyataan yang telah diajukan dan menghafal jawaban atas skala sikap pada pemberian angket pertama. Sebaliknya, secara rasional ingatan subjek terhadap substansi pernyataan-pernyataan dalam angket tersebut belum berkurang atau belum hilang. Kriteria terkait rentang waktu pengulangan perlu diperhatikan karena teknik yang digunakan oleh penulis untuk menguji reliabilitas instrumen adalah teknik pengulangan dengan menggunakan angket yang sama untuk diberikan dalam waktu yang berbeda.

Pelaksanaan pengambilan Data II, seperti halnya pengambilan Data I, dilakukan pada masa kegiatan ujian akhir semester. Namun, jika pada penambilan Data I dilakukan saat jadwal ujian mata kuliah Fisika, pada pengambilan Data II ini dilakukan saat jadwal ujian mata kuliah lain, yaitu bertepatan dengan jadwal mata kuliah Pendidikan Pancasila. Dalam pelaksanaan pengambilan Data II ini, penulis tidak ikut terjun ke ruang ujian, namun sepenuhnya dilakukan oleh teman dosen yang sedang bertugas sebagai pengawas ujian mata kuliah Pendidikan Pancasila tersebut. Karena penulis menggunakan teknik pengulangan untuk menguji kestabilan skor (reliabilitas), maka subjek saat pengambilan Data II sama dengan subjek saat pengambilan Data I, yaitu mahasiswa S1 Ilmu Keolahragaan Angkatan 2011 yang berjumlah 140 mahasiswa.

\section{HASIL DAN PEMBAHASAN}

Seperti yang telah diuraikan sebelumnya bahwa pelaksanaan pengujian reliabilitas instrumen motivasi ini menggunakan teknik pengulangan pemberian angket. Skor-skor yang diperoleh dari pemberian angket saat pengambilan Data I (X) dan pengambilan Data II (Y) tersebut selanjutnya dihitung indeks korelasinya, dengan menggunakan rumus korelasi Pearson Product Moment (rxy). Koefisien korelasi yang diperoleh inilah yang menggambarkan derajat reliabilitas instrumen tersebut.

Adapun korelasi Pearson Product Moment tersebut dihitung dengan menggunakan rumus sebagai berikut (Irianto, 2004: 137).

$r_{x y}=\frac{n \sum X Y-\sum X \sum Y}{\sqrt{n \sum X^{2}-\left(\sum X\right)^{2}} \sqrt{n \sum Y^{2}-\left(\sum Y\right)^{2}}}$

Keterangan:

$\mathrm{n}$ = jumlah responden

$\mathrm{X}$ = skor yang diperoleh masing-masing responden pada pengambilan Data I

$\mathrm{Y}=$ skor yang diperoleh masing-masing responden pada pengambilan Data II

rxy $=$ koefisien korelasiyang menggambarkan derajat reliabilitas instrumen

Selanjutnya, dengan menggunakan rumus tersebut dilakukan perhitungan untuk menentukan nilai rxy. Dan, berdasarkan perhitungan dengan menggunakan program Microsoft Office Excel 2007, diperoleh nilai rxy sebesar 0,948 .
Menurut Vockell (1995), nilai rxy sebesar 0,948 tersebut masuk dalam kategori korelasi positif sangat kuat (namun tidak sempurna). Vockell (1995) mengkategorikan koefisien korelasi $0,80 \leq \mathrm{rxy}<1,00$ sebagai korelasi positif sangat kuat. Sejalan dengan Vockell (1995), Arikunto (2008) juga mengkategorikan nilai rxy sebesar 0,948 tersebut dalam kategori korelasi positif sangat tinggi. Menurut Arikunto (2008), kategori korelasi positif sangat tinggi, yaitu nilai rxy antara 0,81 sampai dengan 1,00 . Ini berarti bahwa instrumen motivasi belajar fisika yang telah dikembangkan dengan menggunakan langkah-langkah seperti yang telah diuraikan sebelumnya tersebut telah memiliki derajat reliabilitas yang sangat tinggi. Derajat reliabilitas instrumen yang tinggi ini menunjukkan bahwa adanya konsistensi yang tinggi terhadap skor yang diperoleh responden saat pengambilan Data I dan Data II. Hal ini juga menunjukkan bahwa konsistensi mahasiswa dalam memberikan responnya, relatif sangat tinggi.

Perhatian penulis pada rentang waktu pengulangan dan "pengontrolan" terhadap adanya tambahan pengalaman responden juga menjadi faktor yang dapat mempengaruhi derajat reliabilitas instrumen tersebut. Hal ini seperti yang diungkapkan oleh Ali (2010) bahwa skor kekeliruan dapat disebabkan oleh rentang waktu pengulangan pelaksanaan pemberian angket atau karena adanya tambahan pengalaman subjek terkait butir-butir pernyataan dalam angket. Oleh karena itu, dengan berasumsi bahwa variabel waktu pengulangan dan pengalaman subjek bersifat konstan, maka skor yang diperoleh responden dari respon yang diberikan pertama kali akan relatif sama dengan skor yang diperoleh responden pada respon yang diberikan saat pengulangan yang kedua.

\section{SIMPULAN}

1. Langkah-langkah yang dilakukan dalam pengembangan instrumen Motivasi Belajar Fisika, meliputi: (1) penentuan aspek-aspek motivasi belajar, (2) perumusan indikatorindikator motivasi belajar fisika, (3) penyusunan butir-butir pernyataan angket motivasi belajar fisika, (4) pengujian keterbacaan, (5) pengujian validitas isi, dan (6) pengujian reliabilitas instrumen.

2. Empat aspek motivasi yang digunakan dalam merumuskan indikator motivasi belajar fisika, yaitu: (1) aspek pilihan atau ketertarikan terhadap tugas/kegiatan, (2) aspek usaha atau upaya yang dilakukan untuk sukses, (3) aspek ketekunan atau kegigihan dalam menyelesaikan tugas, dan (4) aspek rasa percaya diri selama terlibat kegiatan.

3. Instrumen motivasi belajar fisika yang dikembangkan ini telah memiliki nilai keterbacaan Baik, validitas isi juga Baik, bahkan dapat dikatakan Sangat Baik, yaitu dengan nilai 4,52 dari nilai maksimal 5. Sedangkan derajat reliabilitasnya Sangat Tinggi, yaitu dengan ditunjukkan oleh nilai koefisien korelasi sebesar 0,948. 
Derajat reliabilitas instrumen tersebut diperoleh dengan metode test-retest dengan tenggang waktu antara pengambilan Data I dan Data II yaitu selama dua minggu.

4. Pengujian validitas dan reliabilitas instrumen ini dapat dilakukan pada sampel yang lebih besar lagi, serta dengan menggunakan teknik analisis data yang berbeda dan lebih canggih.

\section{DAFTAR PUSTAKA}

Ali, Mohammad. 2010. Metodologi dan Aplikasi Riset Pendidikan. Bandung: Pustaka Cendekia Utama.

Anderson II, James C. 2007. Effect of ProblemBased Learning on Knowledge Acquisition, Knowledge Retention, and Critical Thinking Ability of Agriculture Students in Urban Schools. Dissertation Doctor of Philosophy. University of Missouri- Columbia. Email: JCAnderson@ mizzou.edu

Arends, Richard I. 2012. Learning to Teach, Ninth Edition. New York: McGraw-Hill.

Arikunto, Suharsimi. 2008. Dasar-dasar Evaluasi Pendidikan. Jakarta: Bina Aksara.

Brophy, Jere. 2004. Motivating Students to Learn. Second Edition. New Jersey: Lawrence Erlbaum Associates (LEA).
Christidou, Vasilia. 2011. Interest, attitudes and images related to science: Combining students' voices with the voices of school Science, teachers, and popular science. International Journal of Environmental \& Science Education (IJESE). Vol. 6, No. 2, April 2011, 141-159. ISSN 10363065. http://www.ijese.com/.

Gronlund, Norman E. 2003. Assessment of Student Achievement. Seventh Edition. Boston: Allyn and Bacon.

Irianto, Agus. 2004. Statistik, Konsep Dasar \& Aplikasinya. Jakarta: Kencana.

Kang, H., Scharmann, L. C., Kang, S., \& Noh, T. 2010. Cognitive conflict and situational interest as factors influencing conceptual change. International Journal of Environmental \& Science Education (IJESE). Vol. 5, No. 4, October 2010, 383-Tersedia: http://www.ijese.com/.

Palmer, David. 2005. A Motivational View of Constructivist-informed Teaching. Research Report. International Journal of Science Education. Vol. 27, No. 15, pp. 1853-1881.

Santrock, John W. 2008. Educational Psychology, Third Edition. Boston: McGraw-Hill. 